\title{
Extracorporeal Membrane Oxygenation Experience in the Patient with Acute Respiratory Distress Syndrome After Candida pneumonia
}

\author{
Candida Pnömonisi Sonrası Akut Solunum Sıkıntısı Sendromu \\ Hastasında Ekstrakorporyal Membran Oksijenasyonu Deneyimi
}

\author{
(D) Eyyüp Sabri Özden ${ }^{1}$, (D) Asiye Ceylan ${ }^{1}$, (D) Mehmet Oral ${ }^{2}$ \\ ${ }^{1}$ Memorial Ankara Hospital, Clinic of Anesthesiology and Reanimation, Ankara, Turkey \\ ${ }^{2}$ Ankara University Faculty of Medicine, Department of Anesthesiology and Reanimation, Ankara, Turkey
}

Keywords

Candida pneumonia, ARDS, ECMO

Anahtar Kelimeler

Candida pnömonisi, ARDS, ECMO

Received/Geliş Tarihi : 24.01.2017

Accepted/Kabul Tarihi : 20.04.2017

doi:10.4274/meandros.galenos.2017.36854

Address for Correspondence/Yazışma Adresi: Eyyüp Sabri Özden MD,

Memorial Ankara Hospital, Clinic of

Anesthesiology and Reanimation, Ankara,

Turkey

Phone : +90 5324529236

E-mail :dreyupsabri@gmail.com

ORCID ID: orcid.org/0000-0002-8070-0159

(C) Meandros Medical and Dental Journal, Published by Galenos Publishing House.

This is article distributed under the terms of the

Creative Commons Attribution NonCommercial 4.0

International Licence (CC BY-NC 4.0).

\begin{abstract}
Acute Respiratory Distress syndrome (ARDS) is an acute, diffuse, inflammatory lung injury that leads to increased pulmonary vascular permeability, increased lung weight and loss of ventilated tissue. Since the definition of ARDS, more than $40 \%$ of the mortalities is caused by it despite the significant developments in the management of severe ARDS. The patients who used extracorporeal membrane oxygenation (ECMO) for severe ARDS treatment had lower morbidity and mortality rates. In this case report, a patient with coronary artery disease in whom severe ARDS and septicemia were developed after Candida pneumonia and was treated with ECMO was presented.

Öz

Akut Solunum Sıkıntısı sendromu (ARDS) pulmoner vasküler geçirgenlikte artış, akciğer ağırlığının artması ve havalanan doku kaybına yol açan akut, yaygın, enflamatuvar bir akciğer hasarıdır. Ağır ARDS, ilk tanımlanmasından bu yana yönetimindeki önemli gelişmelere rağmen, \%40'tan fazla mortaliteye neden olmaya devam etmektedir. Ağır ARDS tedavisinde ekstrakorporeal membran oksijenasyonu (ECMO) yapılan hastalar daha düşük morbidite ve mortalite oranlarına sahiptir. Bu olguda koroner arter hastalığı olan Candida pnömonisi sonrası ARDS ve septisemi gelişen hastada ECMO tedavisi uygulanmıştır.
\end{abstract}




\section{Introduction}

Acute Respiratory Distress Syndrome (ARDS) is an acute, diffuse, inflammatory lung injury that leads to increased pulmonary vascular permeability, increased lung weight, and loss of ventilated tissue. ARDS diagnostic criteria include new or worsening respiratory symptoms within a week, bilateral opacities that are compatible with pulmonary edema and cannot be explained by other reasons in chest $\mathrm{X}$-ray or computerized tomography (CT) in the lack of heart failure or loading of excessive fluid to explain respiratory failure and the rate of arterial oxygen pressure $\left(\mathrm{PaO}_{2}\right) /$ fraction of inspired oxygen $\left(\mathrm{FiO}_{2}\right)$ $\leq 300$ when positive end-expiratory pressure (PEEP) is $\geq 5 \mathrm{cmH}_{2} \mathrm{O}$. When PEEP is $\geq 5 \mathrm{cmH}_{2} \mathrm{O}$ with mechanical ventilation, if $\mathrm{PaO}_{2} / \mathrm{FiO}_{2}$ is $\leq 100$, it is defined as severe ARDS (1). Despite the significant developments in the management of severe ARDS since its definition, it causes more than $40 \%$ of the mortalities (2).

Extracorporeal membrane oxygenation (ECMO), which is a kind of extracorporeal life support (ECLS), provides oxygenation and carbondioxide elimination in one of two main configurations, either venoarterial (VA) or venovenous (VV). VV ECMO is used mostly in adult patients and represents $78 \%$ of ECLS use in this population (3). The patients who used ECMO for severe ARDS treatment had lower morbidity and mortality rates (1). In this case report, a patient with coronary artery disease in whom ARDS and septicemia were developed after Candida pneumonia and who was treated with ECMO was presented. However, the patient died on the $7^{\text {th }}$ day of her admission to the intensive care unit.

\section{Case Report}

A 78-year-old woman with diabetes mellitus, hypertension, coronary heart disease, coronary stent and thyroidectomy was admitted to the intensive care unit. Her general condition was poor, she was confused, Glascow Coma Scale (GCS) score was 11 and the oxygen saturation was low $\left(\mathrm{SpO}_{2}\right.$ : 80-90). Informed consent was obtained from the patient and relatives. There were bilateral diffuse ground-glass infiltrations in the chest X-ray. The auscultation of the lungs revealed bilateral coarse crackles.

The arterial blood gas ( $A B G$ ) showed $\mathrm{pH}:$ 7.2, $\mathrm{pO}_{2}: 35 \mathrm{mmHg}, \mathrm{pCO}_{2}: 67 \mathrm{mmHg}$ and $\mathrm{SaO}_{2}: 57$, she was intubated and followed-up with synchronous intermittent mandatory ventilation in pressure support mode on $\mathrm{FiO}_{2}$ : $100 \%$ PEEP: $15 \mathrm{cmH}_{2} \mathrm{O}$ in mechanical ventilator.

A $12 \mathrm{~F}$ central venous catheter was placed and the patient was anaesthetized with $0.4 \mathrm{mg} / \mathrm{kg} /$ hour propofol infusion. In the following hours, the mode was switched to pressure-regulated volume control and recruitment maneuver was applied to the patient. Noradrenaline infusion of $0.15 \mathrm{mcg} / \mathrm{kg} /$ min was added to the treatment of the hypotensive patient and in addition to piperacillin + tazobactam treatment, levofloxacin was added.

According to the trans-thoracic echocardiography, pulmonary arterial pressure was $60 \mathrm{mmHg}$. The patient who was considered to have right heart failure and pulmonary hypertension was started on clopidogrel and sildenafil treatment. The culture from the bronchoalveolar lavage taken with bronchoscopy reported Candida growth. Anidulafungin was started to the patient with multiorgan failure such as hepatic and renal failure.

We decided to start VA ECMO support when the $A B G$ of the patient showed $\mathrm{pH}: 7.15, \mathrm{pO}_{2}: 50.9 \mathrm{mmHg}$, $\mathrm{pCO}_{2} ; 72 \mathrm{mmHg}, \mathrm{SaO}_{2}: 82$. ECMO catheters were placed to the left femoral artery and vein. After the heparine bolus of $80 \mathrm{u} / \mathrm{kg}$, the maintenance infusion was started at the dose of $18 \mathrm{u} / \mathrm{kg} / \mathrm{hr}$. The efficacy of the administered heparine was controlled with activated clotting time (ACT). The ACT was tried to be kept between 150-200. In the follow up, anisocoria was detected in the patient. The GCS was 3-4 so cranial CT was obtained. In cranial CT, a probably acute hemorrhage area with focally characterized diffuse areas of parenchymal hemorrhage which reached to $7.5 \mathrm{~cm}$ at the widest diameter, which was hypodense centrally with a peripheral hyperdence rim that was considered to belong to the hemorrhage and which was at the level of corpus callosum in the middle line and extending partially to the opposite hemisphere, which occurred on the basis of a possible infection or old hemorrhage was observed in left frontal region. There was acute hematoma in the left at the level of basal ganglia and diffuse hemorrhage in the ventricules. There was diffuse hemorrhage also within the cerebellar folia, bilateral sylvian fissures with the right side being more prominent and in the 
subarachnoid spaces in the bilateral fronto-parietal regions.

\section{Discussion}

ARDS was firstly defined in 1967. Ashbaugh et al. (4) reported a mortality rate of $58 \%$ in 12 patients with ARDS. Gille and Bagniewski (5) collected data from 7 countries, 233 ARDS patients were treated with ECMO by 90 health care providers. The cumulative survival rate was $15 \%$.

Between 1986-2006, Brogan et al. (6) examined the registry of Extracorporeal Life Support Organization, which is an international network, to create the first major international multicenter database of ECMO for severe ARDS. That registry included 1.473 patients with a mean age of 34 years and their $78 \%$ were treated with VV-ECMO for the mean duration of 154 hours. The discharge rate and overall survival rate were $50 \%$. Mortality associated risk factors were advanced age, decrease in the patient's weight, prolonged ventilation time before $\mathrm{ECMO}$, arterial blood $\mathrm{pH}$ being lower than 7.18 , underlying reason of respiratory failure and the complications of ECMO. VV ECMO was associated with increased survival compared to VA ECMO. About $9 \%$ of patients had radiographic findings related to cerebral infarction, bleeding or brain death (6).

The most important complication of ECMO in the first years was bleeding. Knoch et al. (7) showed surface-heparinized ECMO circuits and membranes reduced daily blood loss and required intravenous heparin dose. The survival rate was higher in patients treated with heparinized systems. During ECMO treatment, in a study using standard anticoagulation therapy with unfractionated heparin as continuous infusion followed by repeated measurements of ACT or activeted partial thromboplastin time (APTT), ACT values were found to be within the range of $180-220$ second and the target APTT level was desired to be at least 1.5 times higher than the upper limit of the normal reference interval (8). Heparin and albumin coated cannulas were used in our patient. Heparin dose was regulated with ACT follow-ups and it was kept between 150-200.

Intracerebral hemorrhage or infarction in ECMO is a devastating and often fatal complication that occurs $10 \%$ to $15 \%$ of patients with ARDS (9). In the the Australian and New Zealand-ECMO series, $43 \%$ of deaths were associated with intracranial hemorrhage
(ICH) (10). Seventy-four adults who received VA $\mathrm{ECMO}$ at a single center, the $\mathrm{ICH}$ rate was $18.9 \%$. ICH risk increases with female gender, heparin use, renal insufficiency, dialysis need and most importantly, in correlation with thrombocytopenia. Mortality was $92.3 \%$ in patients with $\mathrm{ICH}$ whereas $61 \%$ in non- $\mathrm{ICH}$ patients (11). The emergence of $\mathrm{ICH}$ in the patient who fulfilled all criteria increased the risk of mortality.

The most important complication may be infection and sepsis. The large surface of the synthetic material is prone to colonization and infection. Of ECMO patients, $79 \%$ died from multi-organ failure or septic shock (12). The risk of bacteremia and fungemia is high in ECMO patients, because blood is in contact with artificial surfaces on which bacteria and fungi can easily spread. Cannulas allow skin bacteria to enter the bloodstream. There are no guidelines regarding prophylactic antibiotic or antifungal therapy for ECMO (13). Coagulase-negative Staphylococci and Candida species are common causes of ECMOassociated bloodstream infection, and the risk of infection with Stenotrophomonas maltophilia and Aspergillus species may increase in patients with longterm ECMO treatment (14). Despite the initiation of the treatment for Candida pneumonia in our case, perhaps the ECMO treatment has increased the risk of septicemia.

The incidence of right ventricular failure (RVF) in ARDS was reported as $9.6 \%-25 \%$. The main reason for the development of RVF in ARDS is the increased pulmonary vascular resistance (PVR). Mechanical ventilation with PEEP also causes increase of PVR (15). In the studies on hemodynamic variables of pulmonary hypertension related RVF and survival with pulmonary arterial hypertension, low cardiac index and high mean right atrial pressure were observed to be associated with poor survival (16). When RV failure develops, VV ECMO can be changed to VAV mode to evacuate RV volume and RV shear stress, or VAV mode is preferred for the treatment of RVF and ARDS (17). VA ECMO mode was preferred in our patient with pulmonary hypertension and RVF.

Severe ARDS is associated with high morbidity and mortality rates in patients treated with mechanical ventilation in intensive care units. In recent years, the marked advances in ECMO technology have led to safer initiation and maintenance of this life-saving 
treatment and reduced its risks regarding the patients. However, further well-designed, randomized clinical trials are needed before widespread use of treatment is accepted in suitable patients with severe ARDS.

Ethics

Informed Consent: Informed consent was obtained from the patient and relatives.

Peer-review: Externally peer-reviewed.

Authorship Contributions

Concept: E.S.Ö., A.C., M.O., Design: E.S.Ö., A.C., M.O., Supervision: M.O., Fundings: E.S.Ö., A.C., M.O., Materials: E.S.Ö., A.C., Data Collection or Processing: E.S.Ö., A.C., Analysis or Interpretation: E.S.Ö., A.C., M.O., Literature Search: E.S.Ö., A.C., M.O., Critical Review: M.O., Writing: E.S.Ö., A.C.

Conflict of Interest: No conflict of interest was declared by the authors.

Financial Disclosure: The authors declared that this study received no financial support.

\section{References}

1. Paolone S. Extracorporeal Membrane Oxygenation (ECMO) for Lung Injury in Severe Acute Respiratory Distress Syndrome (ARDS): Review of the Literature. Clin Nurs Res 2016; 26: 747-62.

2. Leligdowicz A, Fan E. Extracorporeal life support for severe acute respiratory distress syndrome. Curr Opin Crit Care 2015; 21: 139.

3. Paden ML, Conrad SA, Rycus PT, Thiagarajan RR. Extracorporeal Life Support Organization Registry Report 2012. ASAIO J 2013; 59: 202-10.

4. Ashbaugh DG, Bigelow DB, Petty TL, Levine BE. Acute respiratory distress in adults. Lancet 1967; 2: 319-23.

5. Gille JP, Bagniewski AM. Ten years of use of extracorporeal membrane oxygenation (ECMO) in the treatment of acute respiratory insufficiency (ARI). Trans Am Soc Artif Intern Organs 1976; 22: 102-8.

6. Brogan TV, Thiagarajan RR, Rycus PT, Bartlett RH, Bratton SL. Extracorporeal membrane oxygenation in adults with severe respiratory failure: a multi-center database. Intensive Care Med 2009; 35: 2105-14.
7. Knoch M, Köllen B, Dietrich G, Müller E, Mottaghy K, Lennartz $\mathrm{H}$. Progress in veno-venous longterm bypass techniques for the treatment of ARDS. Controlled clinical trial with the heparincoated bypass circuit. Int J Artif Organs 1992; 15: 103-8.

8. Sidebotham D, Allen SJ, McGeorge A, Ibbott N, Willcox T. Venovenous extracorporeal membrane oxygenation in adults: practical aspects of circuits, cannulae, and procedures. J Cardiothorac Vasc Anesth 2012; 26: 893-909.

9. Park PK, Napolitano LM, Bartlett RH. Extracorporeal membrane oxygenation in adult acute respiratory distress syndrome. Crit Care Clin 2011; 27: 627-46.

10. Australia and New Zealand Extracorporeal Membrane Oxygenation (ANZ ECMO) Influenza Investigators, Davies A, Jones D, et al. Extracorporeal membrane oxygenation for 2009 influenza A (H1N1) acute respiratory distress syndrome. JAMA 2009; 302: 1888-95.

11. Kasirajan V, Smedira NG, McCarthy JF, Casselman F, Boparai N, McCarthy PM. Risk factors for intracranial hemorrhage in adults on extracorporeal membrane oxygenation. Eur J Cardiothorac Surg 1999; 15: 508-14.

12. Fjalldall $O$, Torfason B, Onundarson PT, Thorsteinsson A, Vigfusson G, Stefansson T, et al. Prolonged total extracorporeal lung assistance without systemic heparinization. Acta Anaesthesiol Scand 1993; 37: 115-20.

13. Kao LS, Fleming GM, Escamilla RJ, Lew DF, Lally KP. Antimicrobial prophylaxis and infection surveillance in extracorporeal membrane oxygenation patients: a multi-institutional survey of practice patterns. ASAIO J 2011; 57: 231-8.

14. Aokage T, Palmér K, Ichiba S, Takeda S. Extracorporeal membrane oxygenation for acute respiratory distress syndrome. J Intensive Care 2015; 3: 17-24.

15. Osman D, Monnet X, Castelain V, Anguel N, Warszawski J, Teboul $\mathrm{JL}$, et al. Incidence and prognostic value of right ventricular failure in acute respiratory distress syndrome. Intensive Care Med 2009; 35: 69-76.

16. D’Alonzo GE, Barst RJ, Ayres SM, Bergofsky EH, Brundage BH, Detre KM, et al. Survival in patients with primary pulmonary hypertension: results from a national prospective registry. Ann Intern Med 1991; 115: 343-9.

17. Lee SH, Jung JS, Chung JH, Lee KH, Kim HJ, Son HS, et al. Right Heart Failure during Veno-Venous Extracorporeal Membrane Oxygenation for H1N1 Induced Acute Respiratory Distress Syndrome: Case Report and Literature Review. Korean J Thorac Cardiovasc Surg 2015; 48: 289-93. 